\title{
Pemberdayaan Masyarakat melalui Pembuatan Jerami Fermentasi untuk Pakan Ternak Sapi di Kecamatan Muara Batu Aceh Utara
}

\author{
Rd. Selvy Handayani ${ }^{*}$, Ismadi ${ }^{1}$, Ariani Kasmiran ${ }^{2}$ \\ ${ }^{1}$ Fakultas Pertanian Universitas Malikussaleh, Kampus Reuleut, Aceh Utara, Aceh \\ ${ }^{2}$ Fakultas Peternakan Universitas Al Muslim, Bireun \\ *Email Korespondensi : selvyt@unimal.ac.id /Hp. 085260109211
}

\begin{abstract}
Abstrak
Keterbatasan jumlah hijauan pakan ternak khususnya dimusim kemarau merupakan suatu kendala dalam meningkatkan produktivitas ternak sapi.Salah satu upaya yang dapat dilakukan adalah dengan memanfaatkan limbah pertanian seperti jerami padi.Jerami padi ternyata tidak dapat dimanfaatkan secara luas pada ternak sapi karena adanya faktor penghambat berupa kandungan nutrisi yang rendah (rendahnya kandungan protein kasar, tingginya serat kasar, lignin dan silika) serta rendahnya kecernaan. Salah satu cara dalam mengatasi masalah ini adalah dengan melakukan pengolahan jerami padi melalui fermentasi. Penyuluhan dan pelatihan pembuatan pakan ternak dengan cara fermentasi jerami sangat perlu dilakukan. Tujuan kegiatan ini adalah meningkatkan kandungan gizi dan kecernaan jerami padi, menjamin ketersediaan pakan ternak sepanjang tahun, dan meningkatkan kesejahteraan masyarakat petani. Penyuluhan dan pelatihan pembuatan jerami fermentasi dilakukan di desa Reuleut Timu kecamatan Muara Batu Aceh Utara. Masyarakat sasaran kegiatan adalah Kelompok tani Ukhwah Sejahtera (bidang pertanian) dan Sapue Pakat (bidang peternakan) yang ada di desa Reuleut Timu. Kegiatan akan dilakukan dari bulan Februari sampai November 2016. Ada dua bentuk kegiatan utama yang akan dilakukan dalam kegiatan ini, yaitu: (1) penyuluhan tentang arti kegunaan dari jerami padi dan manajemen pengelolaan ternak sapi, dan (2) demonstrasi/praktek pembuatan fermentasi jerami. Penyuluhanmerupakan cara penyampaian materi(isi pesan) kepada petani beserta anggota kelompok sasaran,baik secara langsung maupun tidak langsung. Hasil kegiatan menunjukkan bahwa anggota kelompok tani berhasil membuat jerami fermentasi, dan produk jerami fermentasi dapat dikonsumsi dengan baik oleh sapi.
\end{abstract}

Kata kunci: kelompok tani, pakan hijauan, penyuluhan, pelatihan

\section{PENDAHULUAN}

Usaha ternak sapi potong di Indonesia saat ini menjadi sangat penting terutama bila dikaitkan dengan Program Nasional Swasembada Daging Sapi dengan melepaskan ketergantungan impor daging dari luar negeri. Untuk itu kita harus mampu memanfaatkan keberadaan sumberdaya yang kita miliki secara optimal, termasuk sumberdaya ternak potong lokal yakni sapi Aceh yang harus dilestarikan dan sebagai penghasil daging. 
Reuleut Timu adalah salah satu desa binaan yang ada di lingkar kampus Universitas Malikussaleh (Unimal) Lhokseumawe Aceh Utara. Jumlah penduduk Reuleut Timu saat ini adalah 850 jiwa, 90\% diantaranya adalah petani dengan tingkat pendapatan dan pendidikan yang rendah. Mata pencaharian penduduk desa adalah sebagai petani di lahan sawah dan kebun, serta beternak sebagai usaha sampingan. Saat ini terdapat 15 orang petani yang juga beternak sapi potong dengan jumlah 95 ekor sapi. Sebagian besar anggota kelompok tani termasuk kalangan miskin yang perlu diberdayakan. Kondisi ini berdampak pada kehidupan sehari-hari dalam melakukan kegiatan sosial maupun menempatkan diri dalam kehidupan sosial masyarakat. Oleh karena itu Reuleut Timu dipilih menjadi lokasi sasaran kegiatan, sebagai bentuk tanggungjawab sosial Unimal untuk memberdayakan masyarakat sekitar lingkungan kampus.

Pada saat ini ada dua kelompok tani di Gampong Reuleut Timu yaitu Kelompok Tani Ternak Sapue Pakat dan Kelompok Tani Ukhwah Sejahtera.Sejak tahun 2012 tim pelaksana proposal $\mathrm{I}_{\mathrm{b}} \mathrm{M}$ ini telah aktif mendampingi kelompok tani ternak Sapue Pakat. Bentuk pendampingan yang diberikan adalah menginisiasi pembentukan kelompok tani dan membantu pembuatan serta pengajuan proposal ke pemerintah daerah Aceh Utara untuk mendapatkan bantuan sapi potong.Proposal tersebut sudah disetujui oleh bupati Aceh Utara, dan bantuan sapi telah di tahun 2013 sebanyak 25 ekor sapi. Adanya penambahan jumlah sapi di desa Reuleut Timu ini semakin maningkatkan kebutuhan akan pakan ternak yang berkualitas dan mencukupi sepanjang tahun.

Padi merupakan tanaman pertanian utama yang ditanam masyarakat desa Reuleut Timu dan sekitarnya. Jerami padi merupakan limbah tanaman pertanian yang sangat potensial sebagai pakan ternak. Produksi jerami yang melimpah, dapat mencapai 12-15 ton/ha untuk satu kali musim panen. Desa ReuleutTimu memiliki luas sawah 30 ha, maka akan dihasilkan sekitar 450 ton jerami setiap musim panen atau 900 ton jerami per tahun. Jumlah jerami sebanyak itu seharusnya dapat memenuhi kebutuhan pakan ternak untuk kurang lebih 240 ekor sapi/tahun dengan anjuran pemberian $10 \mathrm{~kg}$ jerami/ekor sapi/hari. Jerami padi yang melimpah tersebut ternyata sebagian besar tidak dimanfaatkan bahkan dikategorikan sebagai sampah dan harus segera dibersihkan dengan cara dibakar.

Pemanfaatan jerami padi secara langsung sebagai pakan ternak akan mengalami banyak kendala. Kendala utama adalah kandungan protein yang rendah, namun serat kasarnya tinggi hingga tingkat kecernaan menjadi rendah. Oleh karena itu karakteristik jerami padi sebagai pakan ternak tergolong hijauan bermutu rendah.Penggunaan jerami padi secara langsung atau sebagai pakan tunggal tidak dapat memenuhi pasokan nutrisi yang dibutuhkan ternak. Untuk itu jerami padi tersebut perlu diolah terlebih dahulu dengan teknologi pakan tepat guna melalui fermentasi (Yunilas, 2009).

Fermentasi adalah segala macam proses metabolik dengan bantuan enzim dari mikroba (jasad renik) untuk melakukan oksidasi, reduksi, dan reaksi kimia lainnya sehingga terjadi perubahan kimia pada suatu substrat organik dengan menghasilkan produk tertentu dan menyebabkan terjadinya perubahan sifat bahan tertentu (Winarno dan Fardiaz, 1979). Fermentasi dapat dilakukan dengan cara menambahkan bahan mengandung mikroba proteolitik, lignolitik, selulolitik, lipolitik, dan bersifat fiksasi nitrogen non simbiotik, misalnya starbio, starbio plus, EM-4, ataupun dengan 
pemberian urea, kostik soda $(\mathrm{NaOH})$, dan $\mathrm{CaOH}$. Syamsu (2006) menyatakan bahwa komposisi nutrisi jerami padi yang telah difermentasi dengan menggunakan starter mikroba sebanyak $0,06 \%$ dari berat jerami padi, secara umum menunjukkan peningkatan kualitas dibandingkan jerami padi yang tidak difermentasi.

Kegiatan pengabdian pada masyarakat ini dilakukan dalam lingkup peningkatan pengetahuan, keterampilan dan tingkat pendapatan masyarakat yang ada di lingkar kampus Unimal. Kegiatan ini akan memperkuat petani dalam bidang ekonomi dengan cara pemanfaatan berbagai sumber daya tak termanfaatkan menjadi suatu bahan yang memiliki nilai ekonomi.

Tujuan utama kegiatan ini adalah menjamin ketersediaan pakan ternak berkualitas sepanjang tahun dan meningkatkan kesejahteraan serta meningkatkan pemahaman manajemen pengelolaan ternak sapi.

\section{METODE PELAKSANAAN KEGIATAN}

Penyuluhan dan pelatihan pembuatan jerami fermentasi dilakukan di desa Reuleut Timu kecamatan Muara Batu Aceh Utara. Kegiatan dilakukan dari bulan Maret sampai November 2016. Bentuk kegiatan utama yang akan dilakukan dalam kegiatan ini, yaitu: (1) penyuluhan tentang kegunaan dari jerami padi serta manajemen pengelolaan ternak sapi, dan (2) demontrasi/praktek pembuatan fermentasi jerami.

Bahan yang dibutuhkan adalah jerami sebanyak $1000 \mathrm{~kg}$, probiotik 6 liter (EM4), pupuk urea $6 \mathrm{~kg}$, dan molase (gula cair) 25 liter, air 250-300 liter. Alat yang dibutuhkan adalah parang, sabit, garu, tali rapia, karung plastik, tong air plastik 200 liter, dan selang air, dan alat tulis .

Prosedur pembuatan jerami fermentasi meliputi:

1. Tempat berlantai semen dan beratap disiapkan untuk pembuatan jerami fermentasi, bila memakai drum bagian dalam supaya dicat agar tidak berkarat

2. Jerami kering atau bahan-bahan kering yang telah ada dipotong-potong dengan ukuran kurang lebih $25 \mathrm{~cm}$

3. Larutkan molase dan urea serta EM4 dengan air menjadi satu sesuai perbandingan bahan-bahan di atas.

4. Terpal plastik disiapkan untuk alas mencampur antara jerami dengan campuran larutan molase, EM4, urea dan air.

5. Jerami yang sudah dipotong ditaruh di atas terpal sedikit demi sedikit sambil disiram larutan molase, urea dan EM4 sesuai perbandingan di atas sampai merata dan jerami kelihatan basah.

6. Setelah jarami benar-benar telah tersiram rata dengan larutan tersebut, jerami dimasukkan ke dalam tempat fermentasi, misal dalam kantung plastik bening, sedikit demi sedikit sambil dimampatkan supaya padat.

7. Setelah mampat (padat), tempat fermentasi (plastik bening) ditutup hingga rapat dan dipastikan tidak ada udara yang bisa masuk.

8. Jerami dibiarkan terjadi fermentasi dan diletakkan di tempat terlindung, tidak terkena matahari langsung.

9. Jerami fermentasi dapat diberikan pada sapi setelah 7-21 hari.

10. Jerami padi fermentasi yang belum habis diambil dari tempat fermentasi supaya ditutup kembali dengan rapat 
11. Tempat fermentasi supaya terhindar dari genangan air, terhindar dari terik matahari dan air hujan tidak boleh masuk ke dalamnya

\section{HASIL DAN PEMBAHASAN}

Pengabdian kepada masyarakat meupakan transfer ilmu untuk mencerdaskan masyarakat dan penerapan inovasi teknologi untuk kesejahteraan dan kemakmuran masyarakat. Pengabidan pada masyarakat dilakukan pada Kelompok Tani Ternak Sapue Pakat dan Kelompok Tani Ukhwah Sejahtera yang ada di desa Reuleut Timu kecamatan Muara Batu kabupaten Aceh Utara, yang memelihara ternak sapi.

Kondisi yang dialami oleh peternak di kedua kelompok adalah masalah keterbatasan sumber bahan pakan, kurangnya pengetahuan peternak tentang sumberdaya alam yang dapat dimanfaatkan sebagai sumber pakan ternak sapi, terutama pemanfaatan limbah pertanian berupa jerami. Dari hasil survey awal, peternak memberikan pakan ternak hanya bersumber dari hijauan, sehingga pada musim kemarau peternak akan mengalami kesulitan dalam pemenuhan kebutuhan pakan.

Desa Reuleut Timu memiliki potensi sumberdaya pakan lokal yang melimpah. Sumber pakan lokal itu dapat dimanfaatkan untuk persediaan pakan terutama di masa sulit mendapat pakan ternak, misalnya di musim kemarau. Salah satu sumberdaya lokal yang dapat dijadikan bahan pakan dan tersedia dalam jumlah melimpah adalah jerami.

Petani ternak yang menjadi sasaran kegiatan adalah anggota dari dua kelompok tani di desa Reuleut Timu kecamatan Maura Batu kabupaten Aceh Utara. Tingkat kepemilikan ternak hanya berkisar 1-5 ekor sapi. Pada umumnya petani memberikan makanan dalam bentuk hijauan di musim hujan. Pada saat musim kemarau, mereka kesulitan mendapatkan makanan ternak, sehingga seringkali ternak sapi memakan rumput kering. Petani ternak tidak pernah memberikan jerami untuk pakan sapi.

Para peternak tidak tahu bagaimana cara memanfaatkan sumber pakan jerami. Limbah pertanian ini lebih banyak mencemari lingkungan, sehingga jerami padi hasil panen akan segera dibakar. Dengan adanya penyuluhan tentang sumber daya pakan yang akan dijadikan sumber pakan telah memberikan gambaran bagi peternak bagaimana cara mengolah limbah yang ada di sekitar lingkungannya sebagai sumber pakan ternak. Hal ini akan menyebabkan jumlah ternak sapi yang dipelihara meningkat.

Pada kegiatan pengabdian ini, kelompok ternak sapi dilibatkan dalam proses pembuatan jerami fermentasi secara langsung. Respon masyarakat sangat positif sekali, mereka dengan antusias mengikuti setip kegiatan penyuluhan dan pelatihan. Kegiatan demonstrasi dan pelatihan meliputi cara melihara ternak sapi yang baik, dan pengolahan pakan melalui fermentasi jerami. Petani diharapkan memiliki kemampuan memelihara sapi dengan baik, dan mampu mengolah sendiri jerami padi yang ada di sekitarnya untuk pakan, setelah kegiatan penyuluhan dan pelatihan dilaksanakan (Gambar 1). 

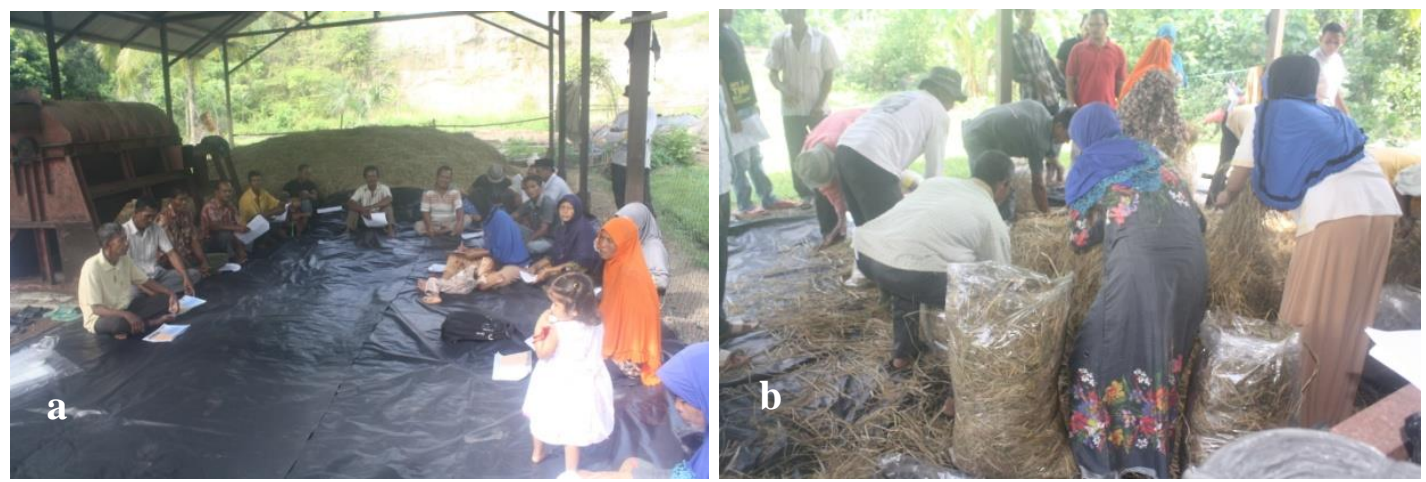

Gambar 1. Kegiatan penyuluhan pelatihan pembuaan jerami fermentasi. (a) Antusias ptani ternak mengikuti penyuluhan; (b) Keaktifan petani ternak mengikuti acara pelatihan.

Hasil pengamatan di lapangan menunjukkan bahwa kegiatan pengabdian ini sangat diserap oleh petani ternak sapi. Mereka terbuka cakrawala pemikirannya tentang sumber daya pakan ternak sapi sehingga keraguan peternak akan keterbatasan pakan akan dapat teratasi. Pengetahuan tentang gizi ternak dirasakan sangat bermanfaat bagi peternak, karena selama ini tidak ada standar dalam pemenuhan pakan bagi ternak sapi.

Evaluasi dilakukan setelah kegiatan penyuluhan dan pelatihan berlangsung. Petani telah mampu mengolah limbah pertanian menjadi pakan ternak. Hasil fermentasi jerami yang dilakukan peternak $100 \%$ berhasil. Hal ini diketahui setelah 10 hari jerami dilakukan pemeraman di dalam karung plastik.

Dari hasil kuosioner yang diberikan kepada peternak tentang pelaksanaan penyuluhan dan demonstrasi serta pelatihan, didapatkan hasil sebagai berikut:

1. $90 \%$ peternak sangat puas terhadap penambahan wawasan tentang teknologi pengolhan pakan ternak

2. $75 \%$ peternak dapat membedakan antara pakan ternak ruminansia dengan pakan ternak unggas

3. $50 \%$ peternak dapat memanfaatkan limbah sebagai pakan dan diberikan dengan imbangan konsenrat

4. $100 \%$ peternak berkeinginan untk memanfaatkan teknologi yang diberikan

Petani ternak dapat membuat jerami fermentasi dengan baik. Hal ini terbukti dari hasil kegiatan, petani ternak tidak mengalami kegagalan, artinya pembuatan jerami fermentasi berhasil $100 \%$. Jerami fermentasi memiliki kadar nutrisi yang lebih baik dibandingkan jerami segar. Tingkat kecernaan bahan kering pada jerami padi hasil fermentasi juga akan meningkat. Hal ini terjadi karena adanya amoniasi jerami padi oleh urea dan molase (Sutama et al., 2016).

Peningkatan kecernaan amoniasi jerami padi yang ditambahkan dengan molase disebabkan karena molase digunakan sebagai sumber energi untuk berkembangbiakan bakteri rumen sehingga mampu memanfaatkan $\mathrm{NH}_{3}$. Selain itu suasana asam tersebut mampu merenggangkan ikatan-ikatan serat yang ada pada jerami padi, sehingga mikroba rumen mampu menghidrolisis dan memfermentasi selulosa, hemiselulosa dan karbohidrat lainnya yang ada pada jerami tersebut. Amoniasi yang hanya menggunakan 
urea juga dapat merenggangkan ikatan-ikatan ester antara lignin dan hemiselulosa maupun ikatan polisakarida sehingga memberi peluang mikroba rumen atau enzim untuk memfermentasi isi sel atau komponen nutrien lainnya. Oleh karena itu kandungan serat kasar dari jerami fermentasi hasil amoniasi dan penambahan molase akan mengalami penurunan (Bata, 2008).

Ada dua reaksi sapi ketika diberi pakan jerami fermentasi. Reaksi pertama, sapi langsung dapat menerima sehingga dapat langsung mengkonsumsinya (75\%), sedangkan respon kedua sapi kelihatan agak enggan mengkonsumsinya (25\%). Oleh karena itu untuk sapi enggan mengkonsumsi jerami fermentasi, harus dilatih sedikit demi sedikit sampai sapi maumengkonsumsinya dengan lahap. Caranya adalah dengan mencampur makanan hijauan dengan jerami fermentasi (3:1), lalu komposisi hijauan harus secara bertahap dikurangi, sampai sapi dapat menerima pakan jerami fermentasi. Jerami fermentasi dan konsumsi jerami fermentasi oleh sapi disajikan pada Gambar 2.
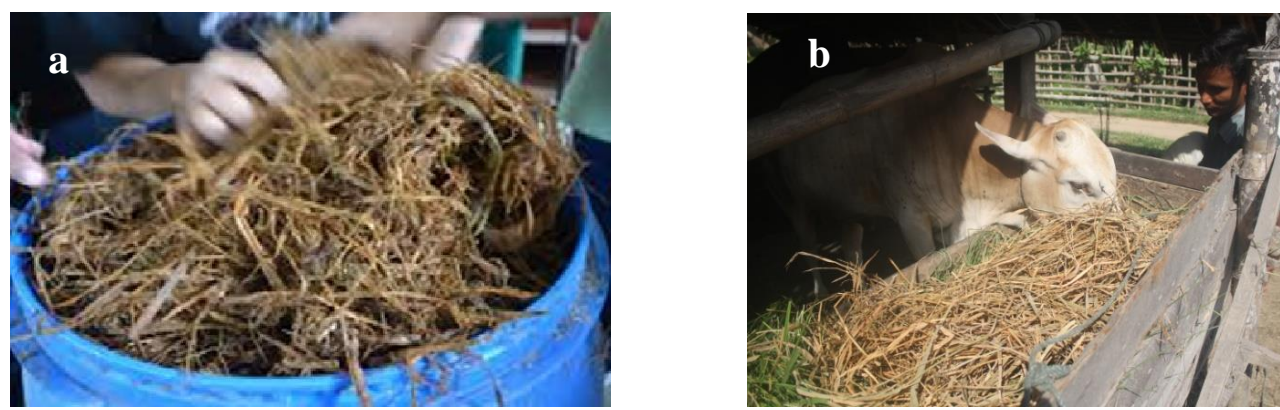

Gambar 2. Jerami fermentasi (a)Konsumsi jerami fermentasi oleh sapi (b)

\section{PENUTUP}

\section{Simpulan}

1. Pembuatan jerami fermentasi $100 \%$ berhasil dilakukan

2. Peternak sapi memilki respon positif terhadap penyuluhan dan demonstrasi serta pelatihan yang dilakukan.

3. $90 \%$ peternak sangat puas terhadap penambahan wawasan tentang teknologi pengolahan pakan ternak. $75 \%$ peternak dapat membedakan antara pakan ternak ruminansia dengan pakan ternak unggas. 50\% peternak dapat memanfaatkan limbah sebagai pakan dan diberikan dengan imbangan konsenrat.

4. $100 \%$ peternak berkeinginan untk memanfaatkan teknologi yang diberikan

5. $75 \%$ sapi dapat mengkonsumsi jerami fermentasi tanpa mengalami kesulitan

\section{DAFTAR PUSTAKA}

Bata, M. 2008. Pengaruh molasis pada amoniasi jerami padi menggunakan urea terhadap kecernaan bahan kering dan bahan organik in vitro. Jurnal Agripet $8(2), 15-20$. 
Rd. Selvy Handayani, Ismadi, Ariani Kasmiran

Hellyward, J., Jamarun, N., Zain, M. TT.Pemanfaatan jerami padi olahan (amoniasi dan fermentasi) untuk pakan ternak sapi potong.www.repository.unand.ac.id [24 Mei2013]

Herdinbisnis. 2012. Tips dan trik peternak canggih : jerami padi fermentasi (silase) sebagai pakan ternak sapi. http://www.herdinbisnis.com/2012/02/tips-dan-trikpeternak-canggih-jerami.html\#.UY76mqJHJ7I. [19 Mei 2013]

Kim, S., Dale, B. E. (2004), 'Global potential bioethanol production from wasted crops and crop residues', Biomass and Bioenergy 26(4), 361-375.

Sutama, I.N.S., Sukada, I.K., Suberata, I.W., Ardika, I.N. 2016. Penerapan teknologi fermentasi jerami padi dengan suplemen campuran urea, kapur, dan molasis, untuk meningkatkan produksi ternak sapi di desa Bebetin. Jurnal Udayana Mengabdi 15(2), 243-247.

Syamsu, JA. 2006. Kajian penggunaan starter mikroba dalam fermentasi jerami padi sebagai sumber pakan pada peternakanrakyat di Sulawesi tenggara. Disampaikandalam seminar nasional bioteknologi.Puslit bioteknologi LIPI. Bogor.

Winarno, FG., Fardiaz, S. 1979. Biofermentasi dan biosintesa protein. Penerbit Angkasa. Bandung

Yunilas.2009. Bioteknologi jerami padi melaui fermentasi sebagai bahan pakan ternak ruminansia. Usu, Medan. 